Journal of Management and Economic
Studies
2019, 1(4): 28-41 DOI: $10.26677 / \mathrm{TR} 1010.2019 .116$
Journal Homepage: https://www.jomaes.org

\title{
Critical Factors That Influence Employee Job Performance on Selected Banks in Nigeria
}

\author{
B. A. Chukwu \\ Department Of Business Administration, Igbinedion University, Okada, Edo State, \\ Nigeria, benedictchukwu103@yahoo.com
}

\begin{abstract}
This study investigated the critical factors that influence employee job performance in banking sector in Nigeria. Most Nigerian Banks are performing below expectation irrespective of high funding due to lack of staff motivation and staff training. Most of staff training are exclusive right of those in the higher echelon of the bank, without due consideration given to those in lower cadre. Majority of staff in lower cadre are stagnated in one position for years without promotion and salary increment. This is common with all the banks in Nigeria. A survey was conducted in this study using questionnaire. The data collected were analyzed using percentages and multiple regression. The result showed that a positive relationship exists between the independent variables staff training, staff compensation, co-worker relationship, staff promotion and the dependent variable employee performance. All the independent variables have significant t-ratio. The results are consistent with the literature. We recommended that employees should be adequately compensated in line with labour market condition and that employees should be given opportunity to attain higher position through display of intelligence and hard work.
\end{abstract}

Keywords: Staff Training, Staff Compensation, Co-worker Relationship, Staff Promotion, Organizational Performance.

\section{INTRODUCTION}

Some of the factors that influence employee job performance are staff compensation, staff training, co-worker relationships and staff promotion (Bilau, 2011). Lack of vital training brings about poor performance (Ruchi, 2012). While lack of support from superior and co-workers also lead to poor performance (Zimmerman, 2009).

Employees do not perform where some of the factors that enhances motivation are not in place. Employees are motivated to work when they are adequately remunerated, promoted as when 
due, offered opportunity for promotion, offered necessary training and assistance by the organization and their colleagues (Chukwu, 2017) .

By binding pay with performance an employer can monitor and control specific activities and level of performance. Employees also need to prove their worth in order to stay longer with the organization by providing quality work or else run the risk of getting their employment terminated. Pay is a determinant of job satisfaction and employees cannot perform when there is dissatisfaction with pay (Edegbogho, 2011).

Use of other motivational tools attached to pay such as fringe benefits will also enhance employees job performance. Use of fringe benefit to reward and recognize employees effort and contribution will serve as a motivational tool to improve employees productivity and performance (Mitchel, 2007).

Absence of vital training would lead to poor performance. Training leads to highly motivated and empowered workforce and improved performance (Price, 2001). In order to sustain the work performance of employees, employees must be developed through training to enable them use their intellectual capabilities to work, which in turn leads to organizational performance. (Kira, Eijnatten \& David, 2010).

Human resource management dimensions greatly influence the employees attitude that affects employee performance and development, and if human resource management systems work effectively, then increase in organizational performance will be seen (Snape \& Rediman, 2009). Absence of support from superior and co-workers decrease employees ability to cope with their job and leads to poor performance (Zimmerman, 2009). Support from co-workers during task accomplishment allows employees to interact fully with their co-worker and obtain their necessary assistance that enhances performance $\left(\mathrm{O}^{\prime}\right.$ Driscoll \& Cooper, 2002). Studies have shown that when co-workers or superiors is supportive of subordinate it leads to favourable outcome for the employee and organization, such as reduced stress, turnover intention, increased commitment, productivity and enhanced performance (Bakker, Demerouti \& Schaufeli, 2003; Eisenberger, Shinglahamber, Vanderberghe, Sucharski \& Rhoades, 2002).

Staff promotion is a vehicle for enhancing employees performance and growth (Kim, 2012). Employee organizational growth enhances performance (Weng, Mcelroy, Mirron \& Liu, 2010). Employee will slack in their duty if their opportunity for advancement to higher position is frustrated (Korsakiene, Stankeviciene, Simielyte \& Talackiene, 2014).

Thwala (2012) described three important factors that affect job performance which consists of ability variables (what is needed to achieve the job performance) motivation variables (what determines the performance) and opportunity variables (that is work environment, temperature, noise level, leadership and characteristics of the job). But this study is investigating the influence of ability and motivational variables. The ability variables are training and co-worker relationship, while motivational variables are staff compensation and staff promotion. The critical factors that influence employee job performance are the most important explanatory variables that are considered important determinants of employee job performance. The influences of factors that are perceived as not important are taken into account by the introduction in the model of random variables.

\section{Problem of the Study}

Most organizations in Nigeria including banks are performing below expectation irrespective of high funding due to lack of will to motivate their employees and give them adequate support and training to enhance their performance. Lack of vital training and co-worker relationship will lead to poor performance (Zimmerman, 2009). Most staff training are exclusive right of 
those in the higher echelon of the organization without due consideration given to those in the lower cadre. Some junior cadre employees are stagnated in one position for years without promotion and salary increment. This is common with all the banks in Nigeria. Employees will not perform where they are not adequately motivated in terms of promotion and compensation (Chukwu, 2017). Employees will slack in their duty if their opportunity for advancement to higher position is impaired (Korsakiene, 2014). By binding pay with performance, an employer can monitor and control specific activities and level of performance. In order to sustain the work performance of employees, employees must be developed through training to enable them use their intellectual capabilities to work which in turn leads to organizational performance (Kira et al, 2010).

\section{Objectives of the Study}

The broad objective of the study is to determine the critical factors that influence job performance in banking industry in Nigeria. The specific objectives of the study are to:

i. examine the extent to which staff training influence employees job performance

ii. determine the extent to which staff compensation influence employees job performance

iii. ascertain the extent to which co-worker relationship influence employee job performance

iv. examine the extent to which staff promotion influence employee job performance.

\section{Hypotheses of the Study}

The following hypotheses were formulated to guide this study.

Ho1: Staff training does not positively influence job performance

Ho2: Staff compensation does not positively influence employee job performance

Ноз: Co-worker relationship does not positively influence employee job performance

Ho4: Staff promotion does not positively influence employee job performance

\section{Significance of the Study}

The study would be of great benefit to the following stakeholders.

1. Employees: The study would be of great benefit to employees to strongly appraise their motivational factor that would enhance their job performance.

2. Managers: The study would help managers of banking industry in finding possible measure/strategies to improve employee job performance.

3. Researcher and Academia: This study would be of great benefit to researchers in business administration and management related field as it would provide empirical evidence for further studies on the area of employee job performance.

\section{Scope of the Study}

The study examined the critical factors that influence employee job performance in banking industry in Nigeria. The scope of this study was delimited to staff of United Bank of Africa Plc, Union Bank plc, First Bank plc, Zenith Bank plc, Access Bank plc, Sterling Bank plc, First City Merchant Bank plc, Guaranty Trust Bank plc, Eco Bank plc in Enugu State. 


\section{Limitation of the Study}

In carrying out this study, the researchers were faced with the following limitations.

1. Limited sample size: The sample size of the study was constrained due to the inability of the respondents to voluntarily participate in the survey.

2. Low response rate: The usage of research instrument was usually constrained with poor response rate and this ultimately affects the sample size. Also the reluctant of respondents to answer the questionnaire in the process of data collections, due to fear of victimization by those in authority was another limitation of the study.

3. Statistical modeling: Another challenge facing the study was statistical modeling of the factors that influence employee job performance. The modeling of the variables staff training, staff compensation, co-worker relationship and staff promotion was also tedious for the researcher. Therefore the technical nature of the study also limits the study under investigation.

\section{LITERATURE REVIEW}

\section{Conceptual Review}

\section{Job performance}

Job performance refers to whether an employee carried out his duty well or not (Thwala. Ajagbe, Enegbama, Bilau \& Long, 2012). Job performance comprises the behaviours that employees do in their jobs that are relevant to the goals of the organization (Thwala et al, 2012). David (2006) described three important factors that affect job performance and these consists of the ability variables (what is needed to achieve the job performance) motivation variables (what determines the job performance (and opportunity variables (that is work environment, temperature, noise level, leadership and characteristics of the job).

Usman, Inuwa \& Dalong (2012) classified job performance as a plan for target achievement, such as achieve all organizational goals, optimize the use of resources, social behavior as relations with others is always helpful to others. Carmeli (2003) define job performance as employees ability to behave in a manner that will yield vital outcome for the success of the organization. Evenson (2006) explained job performance as a combination of employees behaviours. He stated that it can be monitored, measured and evaluated as outcomes at employees level and linked with organizational goals. Employee job performance is an important determinant of organizational success. Huselid (2006) described job performance as a reflection of three characteristics, which are performance related to capacity of an employee to perform, employees' willingness to perform and organization support. Jones, George and Hill (2000) stated that, linkage between the personality and job performance in the organization are categorized into emotional stability, openness, consciousness, agreeableness and extroversion effect, job performance.

\section{Theoretical Review}

\section{Staff Training and Employee Job Performance}

Staff training is a method used to increase job related employee knowledge (Usman et al, 2012). Absence of vital training leads to employee poor performance (Ruchi, 2012). Training leads to highly motivated and empowered workforce and improves performance (Long, Mahantra \& Ajagbe, 2012; Price, 2001). Long et al (2012) stated that through training, organization can ensure a high quality performance from employees and at the same time, employees are able to acquire new skills and knowledge and be able to work more effectively. Kockand Per-Erick 
(2011) described training as a flexible element in the development of an employee as it consists of both formal and informal ways to enhance the effectiveness and efficiency of the employee. Huang (2001) found that training of employees leads towards better organizational performance. Employees who possesses intensive training approach attitude performs well in his duty and helps company to speedily adjust the new distractive organizational performance (Mitki \& Ram, 2007). Kim et al (2012) opined that in order to sustain the work performance employees must be developed through training to enable them use their intellectual capabilities to work which in turn results increase in organizational performance.

\section{Staff Compensation and Employee Job Performance}

Staff compensation is a reward given in exchange of service rendered in an organization (Mohammed, 2012; Okutande, 2014). Staff compensation plays an important role in enhancing performance. Mohammed (2012) argued that staff compensation play vital role in retaining and rewarding a high performance employee. Employees will not perform when they are paid less than what obtains in the labour market (Okuntade, 2014) and will want to leave. Staff compensation is a moderation variable that influence job satisfaction, organizational commitment and performance (Price, 2001). Pay satisfaction and salary raise has great influence on job involvement and performance (Carral, Tower, Judge\& Kohn, 2005). Carral et al (2005) found that pay satisfaction is positively related to involvement and performance. De Gieter \& Hofmans (2015) argues that employees satisfaction with compensation would increase their performance and their engagement in their jobs.

\section{Co-worker Relationship and Employee Job Performance}

Co-worker relationship is the extent to which employees perceived that co-worker offer them support, encouragement and concern (O'Driscoll \& Cooper, 2002). Support from co-worker during task accomplishment allow employees to interact fully with their co-workers and obtain the necessary assistance that enhances performance (O Driscoll \& Cooper, 2002). Co-worker relationship also conveys feelings of energy, enthusiasm and general feelings of positive effect when co-worker or supervisor is supportive of subordinate. It leads to favourable outcome for the employees and organization, such as reduced stress, turnover intention, increased commitment, increased productivity and enhanced performance (Bakker et al, 2003; Eisenberger et al, 2002). Support from co-workers, supervisors and organization will increase employee ability to cope with their job and enhance performance (Marker, 2007). Employee will slack up in their duties when they do not perceive support from their supervisor and organizations (Marker, 2007). Kraimer, Seibert, Wayne, Liden \& Bravo, 2001) also found that organizational support is positively related to job performance and satisfaction when the organization offers development and career advancement.

\section{Staff Promotion and Employee Job Performance}

Staff promotion is an upwards movement of employees in his area of specialization (Adeboye \& Adegoroye, 2012). Staff promotion is a vehicle for enhancing employees job performance and growth (Kim, 2012). Weng et al (2010) stated that employees organizational growth enhances performance and could be captured by four factors, career goal progress, professional ability development, promotion speed and remuneration growth. Promotion and work design are major reason for employee job performance and are the major reason employees decide to join, remain or leave an organization.

Employees slack up in their duty if their opportunity for advancement to higher position in the organization out of hard work is frustrated (Korsakiene et al, 2014). Fairness is a critical point concerning promotion (Parker, Noun \& Hayes, 2011). Parker et al (2011) stated that a strong link 
between performance and promotion leads to high perception of justice and satisfaction of employees. Promotion need to be transparent to increase employees willingness to perform Kaplan \& Ferns, 2001).

\section{METHODOLOGY}

Survey research design was utilized to gather information or data from staff of United Bank for Africa Plc, Union Bank Plc, First Bank Plc, Zenith Bank Plc, Access Bank Plc, Sterling Bank Plc, First City Merchant Bank Plc, Guaranty Trust Bank Plc, Eco Bank Plc in Enugu state. The population of the study was 720 . Samples of 254 were selected from the study using Yamane (1964) formular. A stratified random sampling technique was used to distribute sample to the various banks above; using stratum allocation of Kumar (1976). Sampling was conducted on 254 respondents using questionnaire instrument. The questionnaire was made up of 5 point Likert scale. For each variable, there were four items/elements which were deployed keeping in view the questionnaire filling culture and understanding of the population. The questionnaire is a combination of adaption from the proposed five dimensions model for job satisfaction by Zhang and Liao (2007) and self development of items. The demographic data was part of the questionnaire. A total of 254 questionnaires were distributed to staff of the banks above and 202 responses were collected, which has $79.52 \%$ response rate. The reliability coefficient of the questionnaire was measured using Cronbach's Alpha. The reliability coefficient was 0.832 . This means that the data collected were valid and reliable enough for analysis. There are five variables in total in the model, where there are four independent variables and one dependent variable. The independent variables are staff training, staff compensation, co-worker relationship, staff promotion and one dependent variable employee job performance. As the data consists of single dependent variable and multiple independent variables, multiple regressions analysis was deployed and SPSS 16.0 was used to generate results. Descriptive method of analysis were utilized to analyze data from questionnaire instrument using percentages. Hypothesis testing were carried out using multiple regression analysis.

\section{Validity and Reliability of Instrument}

\section{Pilot Test}

A pilot test was carried out on 50 respondents before questionnaire distribution in other to collect their comments, ensure simplicity and understanding of the questionnaire, which helped in developing the questionnaire more efficiently. A favourable comment was obtained from the 50 respondents and the results of the pilot test ensured that the survey was understandable by the 50 respondents.

The reliability analysis was conducted on staff training, staff compensation, co-worker relationship and staff promotion. Table 1 showed the reliability analysis of questionnaire, and the result showed that the reliability coefficient of questionnaire ranged from 0.772-0.896. The reliability coefficient of the questionnaire was 0.832 . This means that the data collected were valid and reliable enough to be used for analysis. Walonick (1993) stated that the values above 0.7 are considered acceptable, and the value above 0.8 are preferable good. 
Table 1: Result of reliability analysis.

\begin{tabular}{|lll|}
\hline Variables & items & Cronbach's Alpha \\
\hline Staff Training & 4 & .772 \\
\hline Staff Compensation & 4 & .821 \\
\hline Co-worker Relationship & 4 & 0.896 \\
\hline Staff Promotion & 4 & 0.768 \\
\hline Job performance & 4 & 0.902 \\
\hline & \\
Source: Authors computation, 2018 & \\
\hline
\end{tabular}

\section{Model Specification}

In order to identify the factors that influence employee job performance, a multiple regression model is used. The regression model used is specified as follows.

$\mathrm{EJP}=\beta_{0}+\beta_{1} \mathrm{ST}+\beta_{2} \mathrm{SC}+\beta_{3} \mathrm{CR}+\beta_{4} \mathrm{SP}+\mu$

Where

EJP $=$ Employee Job Performance

$\beta_{1} \mathrm{ST}=$ Staff Training

$\beta_{2} \mathrm{SC}=$ Staff Compensation

$\beta_{3} \mathrm{CR}=$ Co-worker Relationship

$\beta_{4} \mathrm{SP}=$ Staff Promotion

$\beta_{0}=($ Beta zero) Y-intercept of the line

$\beta_{i}=(i=1,2,3,4)$ are estimates of the coefficient

$\mu=$ an error term measuring variation in employee performance that is unaccounted for by the independent variables.

\section{DATA PRESENTATION, ANALYSIS AND INTERPRETATION}

Data presentation and analysis for sample background variables. A total of two hundred and fifty seven (254) questionnaires were given out to respondents and two hundred and two (202) were dully returned and usable, and subsequently analyzed. Therefore the response rate was $79.52 \%$. The demography of respondents was presented in table 2 below.

Table 2: Demography of Respondents

\begin{tabular}{|l|l|l|}
\hline \multicolumn{1}{|c|}{ Respondents } & \multicolumn{1}{|c|}{ Frequency } & \multicolumn{1}{c|}{ Percentage (\%) } \\
\hline Age: & \multicolumn{1}{|c|}{} \\
\hline Below 30 years & 42 & 20.8 \\
\hline $30-39$ years & 83 & 41.2 \\
\hline $40-49$ years & 53 & 26.2 \\
\hline 50 years and above & 24 & 11.8 \\
\hline Total & $\mathbf{2 0 2}$ & $\mathbf{1 0 0 . 0}$ \\
\hline Sex: & & \\
\hline Male & 136 & 67.3 \\
\hline Female & 66 & 32.7 \\
\hline Total & $\mathbf{2 0 2}$ & $\mathbf{1 0 0 . 0}$ \\
\hline
\end{tabular}




\begin{tabular}{|l|l|l|}
\hline Educational Level: & & \\
\hline Secondary & 57 & 28.2 \\
\hline Post-secondary & 80 & 39.6 \\
\hline Polytechnic/ University & 68 & 32.2 \\
\hline Total & $\mathbf{2 0 2}$ & $\mathbf{1 0 0 . 0}$ \\
\hline Department: & & \\
\hline Accounting & 22 & 10.9 \\
\hline Marketing & 50 & 24.8 \\
\hline Administration & 31 & 15.3 \\
\hline Production & 65 & 32.2 \\
\hline Maintenance & 34 & 16.8 \\
\hline Total & $\mathbf{2 0 2}$ & $\mathbf{1 0 0 . 0}$ \\
\hline Marital Status & & \\
\hline Single & 71 & 35.1 \\
\hline Married & 131 & 64.9 \\
\hline Total & $\mathbf{2 0 2}$ & $\mathbf{1 0 0 . 0}$ \\
\hline Source: & & \\
\hline
\end{tabular}

Source: Field survey, 2018

Table 2 above shows the age distribution of the sampled respondents of whom, $42(20.8 \%)$ of them were age below 30 years, $83(41.2 \%)$ of them were aged $30-39$ years, 53(26.2\%) of them were aged $40-49$ years and $24(11.8 \%)$ of them were aged 50 years and above. This shows that majority of the respondents were aged $30-39$ years. On the issue of sex of sample respondents, $136(67.3 \%)$ were males and $66(32.7 \%)$ were females. This implies that majority of the respondents were males. On the educational level of the respondents who returned valid copies of distributed questionnaires of whom $57(28.2 \%)$ of them attended secondary school, 80 (39.6\%) of them attended post secondary school and $65(32.2 \%)$ of them attended polytechnic/university. This implies that majority of the sampled respondents attended post secondary school. Based on the department $22(10.9 \%)$ of the respondents were in accounting department $50(24.8 \%)$ of the respondents were in the marketing department, $31(15.3 \%)$ of the respondents were in administration department, $65(32.2 \%)$ of the respondents were in production department, 34 $(16.8 \%)$ of the respondents were in maintenance department. This implies that majority of the respondents were in the production department. On the issue of marital status of sampled respondents $71(35.19 \%)$ of them were single and 131 (64.9\%) of them were married. This shows that majority of the respondents were married.

\section{Presentation of Data Collected and Used for Regression Analysis}

Table 3: Distribution of Responses on Questions on Independent Variables

\begin{tabular}{|l|l|l|l|l|l|}
\hline $\begin{array}{l}\text { Independent } \\
\text { variables }\end{array}$ & $\begin{array}{l}\text { Strongly } \\
\text { agree }\end{array}$ & Agree & Undecided & Disagree & $\begin{array}{l}\text { Strongly } \\
\text { disagree }\end{array}$ \\
\hline Staff Training & $52(25.7)$ & $65(32.2)$ & $12(5.9)$ & $50(24.8)$ & $23(11.4)$ \\
\hline $\begin{array}{l}\text { Staff } \\
\text { compensation }\end{array}$ & $98(48.5)$ & $64(31.7)$ & $3(1.5)$ & $23(11.4)$ & $14(6.9)$ \\
\hline $\begin{array}{l}\text { Co-worker } \\
\text { relationship }\end{array}$ & $68(33.7)$ & $72(35.6)$ & $5(2.5)$ & $32(15.8)$ & $25(12.4)$ \\
\hline $\begin{array}{l}\text { Staff } \\
\text { promotion }\end{array}$ & $40(19.8)$ & $13(6.4)$ & $8(4.0)$ & $84(41.6)$ & $57(28.2)$ \\
\hline
\end{tabular}

Source: Field survey, 2018 
Figures that are not in bracket in table 3 show that number of responses, while those that are in bracket show percentage of responses.

Table 4: Distribution of Responses to Questions on Dependent Variable

\begin{tabular}{|l|l|l|l|l|l|}
\hline Dependent variable & $\begin{array}{l}\text { Strongly } \\
\text { agree }\end{array}$ & Agree & Undecided & Disagree & $\begin{array}{l}\text { Strongly } \\
\text { disagree }\end{array}$ \\
\hline $\begin{array}{l}\text { Employee job } \\
\text { performance }\end{array}$ & $35(17.3)$ & $75(37.1)$ & $62(30.7)$ & $26(12.9)$ & $4(2.0)$ \\
\hline
\end{tabular}

Source: Field survey, 2018

Figures that are not in bracket in table 4 show the number of responses, while those that are in bracket show percentage of responses.

\section{Multiple Regression Technique}

The study employed multiple regression to test the formulated hypotheses given the individual significance of the variables and the results were presented in table 5 below.

Table 5: Multiple Regression Result

\begin{tabular}{|l|l|l|l|l|}
\hline Variable & Coefficient & Std error & t-statistic & Prob. \\
\hline Constant & 3.855 & 0.631 & 6.098 & .000 \\
\hline Staff Training & 0.415 & 0.086 & 4.806 & .001 \\
\hline $\begin{array}{l}\text { Staff } \\
\text { compensation }\end{array}$ & 0.617 & 0.097 & 6.342 & .003 \\
\hline $\begin{array}{l}\text { Co-worker } \\
\text { relationship }\end{array}$ & 0.641 & 0.094 & 6.794 & .000 \\
\hline Staff promotion & 0.439 & 0.079 & 5.539 & .004 \\
\hline
\end{tabular}

$\mathrm{R}^{2} \quad 0.618$

Adjusted $\mathrm{R}^{2} \quad 0.611$

F statistics $20.556[0$

Stand error $\quad 0.416$

Statistical Package for Social Science (SPSS) version 16.

\section{Interpretation of Results}

\section{Test of Hypotheses}

Hypothesis 1: Staff training does not positively influence employee job performance. The beta value shows that 1 unit positive change in the value of training would result in 0.415 units $(41.5 \%)$ positive change in employee job performance, other variables being held constant. This in essence entails that staff training is a function of employee job performance. Staff training shows statistically significant unique contribution in explaining employee performance with $(\mathrm{p}<.01)$; while the $\mathrm{t}$-statistics of staff training accounted for significant positive variation in 
dependent variable, that is employee job performance $(\mathrm{t}=4.806, \mathrm{P}<.01)$. Resultantly, null hypothesis was rejected and alternate hypothesis accepted. Meaning that staff training exerts significant influence on employee performance and have positive relationship with employee job performance. This result aligns with the theory which states that through training, organization can ensure a high quality performance from employees and at the same time, employees are able to acquire new skills and knowledge and be able to work effectively.

Hypothesis 2: Staff Compensation does not Positively Influence Employee Job Performance

The beta value shows that 1 unit positive change in the value of staff compensation would result in 0.617 units $(61.7 \%)$ positive change in employee job performance, other variables being held constant. This in essence entails that staff compensation is a function of employee job performance. Staff compensation shows statistically significant unique contribution in explaining employee job performance with $(\mathrm{p}<.01)$, while the t-statistics of staff promotion also accounted for significant positive variation in dependent variable, that is employee job performance $(\mathrm{t}-6.342, \mathrm{P}<.01)$. Resultantly, null hypothesis is rejected and alternate hypothesis accepted. Meaning that staff compensation exerts significant influence on employee job performance and have positive relationship with employee job performance. This result accords with the theory which states that pay satisfaction and salary raise has great influence on job involvement and performance and that employees satisfaction with compensation would increase their performance and engagement in their jobs

Hypothesis 3: Co-worker relationship does not positively influence employee job performance

The beta value shows that 1 unit positive change in the value of Co-worker relationship would result in .641 units $(64.1 \%)$ positive change in employee job performance, other variables being held constant. This in essence entails that Co-worker relationship is a function of employee job performance. Co-worker relationship shows statistically significant unique contribution in explaining employee job performance with $(\mathrm{p}<.01)$, while the $\mathrm{t}$-statistics of co-worker relationship accounted for significant positive variation in dependent variable that is employee job performance $(\mathrm{t}=6.794, \mathrm{P}<.01)$. Resultantly, null hypothesis is rejected and alternate hypothesis accepted. Meaning that Co-worker relationship exerts significant influence on employee job performance and have positive relationship with employee job performance. This result aligns with the theory which states that support from superior and co-worker will increase employee ability to cope with their job and enhance their performance. Employees will slack up in their duties when they do not perceive support from their superior, co-worker and organization.

Hypothesis 4: Staff promotion does not positively influence employee job performance

The beta value shows that 1 unit positive change in the value of staff promotion would result in 0.439 units $(43.9 \%)$ positive change in employee job performance, other variables being held constant. This in essence entails that Staff promotion is a function of employee job performance. Staff promotion shows statistically significant unique contribution in explaining employee job performance with $(\mathrm{p}<.01)$, while the $\mathrm{t}$-statistics of staff promotion also accounted for significant positive variation in dependent variable, that is employee job performance $(t=5.539, \mathrm{P}<.01)$. Resultantly, null hypothesis is rejected and alternate hypothesis accepted. Meaning that Staff promotion exerts significant influence on employee job performance and have positive relationship with employee job performance. This result accords with theory which states that staff promotion is a vehicle for enhancing employees job performance and growth and that employees will slack up in their duty if their opportunity for advancement to higher position in the organization out of hard work is frustrated. 


\section{Discussion of Findings}

The multiple regression result in table 5 reflects the regression model that was developed using employee job performance as the dependent variable and staff training, staff compensation, coworker relationship and staff promotion as the independent variables. Considering the results obtained in table 5, the individual coefficients $\beta$ in case of each and every variable indicates a positive results overall.

A positive relationship lies between the independent variable staff training and the dependent variable employee job performance. This result is consistent with the researches of Long et al (2012), Ruchi, (2012), Kock and Per-Erick, (2011) and Mitki and Ram (2007).

A positive relationship also exists between the independent variable staff compensation and the dependent variable employee job performance. This result is consistent with the researches of Okuntade (2014), Mohammed (2012) Carral et al (2005) and De Gieter and Hofman (2015).

There is a positive relationship between the independent variable co-worker relationship and the dependent variable employee job performance. This result is consistent with the researches of O'Driscoll and Cooper (2002) Bakker et al (2003) Eisenberger et al (2002) Marker (2007) and Kraimer et al (2011).

There is also a positive relation between the independent variable staff promotion and the dependent variable employee job performance. This is consistent with the result of Kim (2012) Korsakiene et al (2014) and Parker et al (2011).

The whole analysis showed that the independent variables staff training, staff compensation, co-worker relationship and staff promotion regressed the dependent variable employee job performance and provides considerable outcome where significant value $(p)$ is less than $0.01, F$ value is equal to 20.556 an $R$ square is greater than 0.60 , while less than 1 value is observed from the standard error. $R^{2}$ shows that the model is a fit one. $F=20.556<0.00$ shows that the model has overall significance at $1 \%$ level. $\mathrm{R}^{2} 0.618$ suggest that the model has a good fit. This indicates that $61.8 \%$ variation in employee performance is accounted for by the variation in explanatory variables, suggesting that the model has a good explanatory power on the changes in employee job performance among variables.

\section{Conclusion}

It is concluded that the predictor variables, staff training, staff compensation, co-worker relationship and staff compensation have positive relationship with employee job performance. All the variables have statistical significant t-ratio. The results are consistent with the literature.

\section{Recommendations Based on Research Findings}

1. The study recommended that management should conduct regular training programmes to enhance performance of employee and the organization, but it should be done with employees that are focus driven with the goals of the organization.

2. The study recommended that employee should be adequately remunerated inline with what obtains in the labour market and not what the corporate guideline dictates. And that remuneration should be based on performance.

3. The study recommended that superior and co-workers should be supportive to subordinates and mates to enable them cope with their job and enhance performance.

4. The study recommended that employees should be given opportunity to attain higher position through display of intelligence and hardwork. 


\section{REFERENCES}

Adeboye, T.A \& Adegoroye, A.A (2012).Employees' perception of career progression and turnover intention among bank workers in Ife Central Local Government Area.Osun State, Research Journal in Organizational Psychology \& Educational Studies, 1, 253 - 360

Bakker, A.B; Demeronti, E \& Schaufeli, W.B (2003). Anal process at work in a call centre : An application of the job demands resource made. European Journal of Work and Operational Psychology 12, $398-417$.

Bilau, A.A (2011). The development of small and medium sized construction firms in Nigeria. using absorptive capacity. Being an Msc thesis submitted to the Graduate School of faculty of civil engineering University Technology Malaysia.

Carral, S.C, Tower, A.J, Judge, T.A \& Kohn, L. (2005). Pay satisfaction and Organizational outcomes Personnel Psychology58, $613-640$.

Carmelli, A. (2003). The relationship between emotional intelligence and work attitudes, behavior and outcome. Journal of Management Psychology 18, 788 - 813

Chukwu, B.A (2017). Determinants of employee turnover intention in food and beverage industry in Nigeria. PhD thesis of Igbinedion University, Department of Business Administration, Okada, Nigeria.

David, C.M (2006). The Achieving Society. New York. Van Nostrand company

De Grieter, S. \& Hofman, J. (2015). How reward satisfaction affects employee turnover intention and performance: An individual difference approach. Human Resource Management Journal 25, $200-216$.

Edegbogho, O. (2011). Training artisan on site. Australian Journal of Construction Economics and Bindery 11, 82 - 91.

Eisenberger, R., Shingihamber, F., Vandengergher, C. ,Sucharski, L., Rhoads, L. (2002). Preserved organizational support contribution to perceived organizational support and employee retention, Journal of Applied Psychology 87, 565 - 573.

Evenson, R. (2006). Motivating to develop an all-stat team. American Salesman 42, 21 - 27.

Huselid, M.A (2006). The impact of human resource management practices on turnover, productivity and corporate financial performance. Academy of Management Journal 38, 635 -672 .

Jones, G.R., George, J.M \& Bill, C.W (2000).Contemporary Management2 ${ }^{\text {nd }}$ (eds) New York: Irwin McGraw Hill

Kaplan, D.M \& Ferris, G.R (2001) Fairness perceptions of employees promotion systems: A twostudy investigation of antecedent and mediators. Journal of Applied Social Psychology 31, $496-519$.

Kraimer, M.L., Seibert, S.W, Wayne, S.J, Liden, R.C \& Bravo, J. (2001). Antecedents and outcomes of organizational support for development: The critical role of career opportunities. Journal of Applied Psychology 94, 485 - 500.

Kira, M., Van, Eijnatten, F.M, David, B.B (2010).Crafting sustainable work: Development of personal resources. Journal of Organizational Change Management. 23, 616-632

Kumar, S. (1976).A manual of Sampling Technique London. Heinemann. 
Kock, H \& Per-Erik, E. (2011).Formal and integrated strategies for competence development in SMES. Journal Eur. Indus. Train. 35, $71-88$.

Kim, S. (2012). The impact of human resource management in state government IT employees turnover intention Public Personal Management 41, 2.

Korsakiene, R. Stankeviciene, A., Simielyte, A. \& Talackiene, M. (2014). Factor driving turnover and retention of information technology professionals. Journal of Business Economics $\mathcal{E}$ Management.

Long, C., Perumal, P. \& Ajagbe, A.M (2012). The impact of human resource practices on employees turnover intention. A conceptual model; Interdisciplinary Journal of Contemporary Research in Business 4, 629-641.

Marker, M (2007).Turnover drivers and retention factors. Management Review 2, 14 - 27.

Mohammed, R.M (2012). Crafts skills availability in the Nigerian construction industry.Journal of Nigerian Association of Engineering 4, 1- 10.

Mitki, Y \& Ram, H (2007).Innovative training in designing corporate identity Indus. Commer. Trans, 39, $174-179$.

Mitchel, T.R (2007). An Alternative Approach: The unfolding model of voluntary employee turnover Academy of Management 12, 50 - 89.

O’Driscoll, M.P \& Cooper, C.L (2002).Job Related Stress and Burnout MP Mar (eds) Psychology at work London: Peguin Books.

Okuntade, I.F (2014). Construction technician training: Its relevance to modern construction industry in Nigeria. International Journal of Technological. Enhancement and Emerging Engineering Research 2, $234-243$.

Parker, R.J, Nouri, H \& Hayes, A, F. (2011).Distributive justice, promotion instrumentality and turnover intention in public accounting firms. Behavioural Research in Accounting 23, 169 186.

Price, J.L (2001) Reflection of the determinant of voluntary turnover, Journal of Man Power 22, $600-624$.

Ruchi, H. (2012).Skills knowledge and organizational performance Research paper 3 November. Unpublished.

Snape, I \& Redman (2009). HRM dimension organizational citizenship behavior and performance. A multi-level analysis. Journal of Management Studies 47, 1219 - 1247

Thwala, D. W, Ajagbe, A.M, Enegbama, S.C, Brilan, A.A \& Long S.C. (2012).Suddanese small and medium size construction firm; An empirical survey of job turnover. Journal of Basic Applied Scientific Research 2, $7141-7420$.

Weng, Q. X., Mcelroy, J. C, Morrow P.C \& Lin, P (2010).The relationship between career growth and organizational commitment. Journal of Vocational Behaviour 77, $391-400$.

Usman, N.D., Inuwa, L.I, Iro, A. I. \&Donlong, J.S (2012). Training of contractors, craftsman, for productivity, improvement in Nigeria Construction Industry. Journal of Applied Science Vol. 3 Dec.

Yamane, T. (1964).Statistics: An Introductory Analysis Haper and Row Publishers, New York. 
Walonick, D.A (1993). The research process available at www.stat.pac.com/resesarch paper/research processhtm. (Accessed 24 sept. 2010)

Zhang, S. J. \& Liao J.O. (2007). An empirical study on the influences of dimension of employee's job satisfaction on total job satisfaction Journal of Science and Management 8, 184 -188 doi 10.3969/j.issn. 1002. 0241. 2007.08. 36 .

Zimmerman, K. (2009). The impact of job performance an employee turnover and the voluntary turnover process, a meta-analysis and path model Personnel Review38, 142 - 158. 